\title{
HANDEL BRONIĄ W REGIONIE AMERYKI ŁACIŃSKIEJ I KARAIBÓW W LATACH 2008-2020
}

\author{
Ireneusz Topolski \\ Uniwersytet Marii Curie-Skłodowskiej w Lublinie \\ Wydział Politologii i Dziennikarstwa, Instytutu Nauk o Polityce i Administracji, \\ Katedra Stosunków Międzynarodowych \\ ORCID ID: https://orcid.org/0000-0001-7152-8329 \\ e-mail: ireneusz.topolski@poczta.umcs.lublin.pl
}

\begin{abstract}
Streszczenie: Handel bronią wpływa na rozbudowę potencjału militarnego przez państwa, a tym samym na ich międzynarodową pozycję militarną. Pośrednio jest on także powiązany z porozumieniami dotyczącymi kontroli zbrojeń, a szczególnie dotyczącym transferu uzbrojenia i sprzętu wojskowego. Potencjał militarny państw Ameryki Łacińskiej i Karaibów jest bardzo zróżnicowana. Dodatkowo części z nich podjęła modernizację swoich armii, połączoną z zakupami uzbrojenia. W konsekwencji prowadzi to do pojawiania się różnych subregionalnych wyścigów zbrojeń. Jednak region mimo występowania sporów terytorialnych i granicznych uważa się za stabilny, a ryzyko wybuchu konfliktu zbrojnego o charakterze międzynarodowym jest niskie. Natomiast dominujące w Ameryce Łacińskiej i Karaibach zagrożenia niemilitarne o podłożu wewnętrznym wpływają znacząco na utrzymanie bezpieczeństwa wewnętrznego. Powyższe problemy przekładają się na poziom handlu bronią w regionie. W niniejszym artykule poddano analizie kwestie dotyczące podejścia państw Ameryki Łacińskiej i Karaibów do porozumień związanych z handlem bronią. Ze względu na złożoność tematu, scharakteryzowane zostaną najważniejsze problemy dotyczące poziomu eksportu i importu uzbrojenia oraz sprzętu wojskowego, jak też główni dostawcy techniki wojskowej do państwa regionu.
\end{abstract}

Slowa kluczowe: Ameryka Łacińska i Karaiby, handel bronią, porozumienia o handlu bronią, dostawcy uzbrojenia, import uzbrojenia, eksport uzbrojenia.

W niniejszym artykule zostanie scharakteryzowany problem handlu bronią ${ }^{1}$ w Ameryce Łacińskiej i Karaibach ${ }^{2}$ w latach 2008-2020. Ze względu na jego ograniczoną objętość, skoncentrowano się na analizie poziomu importu techniki

1 Kategorie uzbrojenia objęte międzynarodową kontrolą, zobacz: I. Topolski, Kontrola i redukcja zbrojeń, [w:] Międzynarodowe Stosunki Polityczne, M. Pietraś (red.), Lublin 2021, s. 526-527.

2 Pojęcie regionu Ameryki Łacińskiej i Karaibów, zobacz: K. Krzywicka, Ameryka Łacińska i Karaiby, [w:] Międzynarodowe Stosunki Polityczne, M. Pietraś (red.), Lublin 2021, s. 307-308; The Military Balance 2021, International Institute for Strategic Studies, London 2021, s. 380-433; 
wojskowej do państw regionu oraz przedstawieniu najważniejszych dostawców, w oparciu przede wszystkim o dane Sztokholmskiego Instytutu Badań dla Pokoju $(\mathrm{SIPRI})^{3}$. Ponadto tylko zasygnalizowany został eksport broni przez te państwa.

Handel bronią wpływa na rozbudowę potencjału militarnego przez państwa, a tym samym na ich międzynarodową pozycję militarną. Ponadto, jest też powiązany z międzynarodową kontrolą i redukcją zbrojeń. Pozycja militarna państw w regionie Ameryki Łacińskiej i Karaibów jest bardzo zróżnicowana. W przypadku części sił zbrojnych została podjęta ich modernizacja jakościowa, połączona z zakupami uzbrojenia, która uwzględniająca również specyfikę uwarunkowań geograficznych. W konsekwencji prowadzi to do pojawiania się różnych subregionalnych wyścigów zbrojeń. $Z$ drugiej strony, region mimo występowania sporów terytorialnych i granicznych uważa się za stabilny, a ryzyko wybuchu konfliktu zbrojnego o charakterze międzynarodowym jako niskie. Jednak dominujące w Ameryce Łacińskiej i Karaibach zagrożenia niemilitarne o podłożu wewnętrznym wpływają znacząco na utrzymanie bezpieczeństwa wewnętrznego. W konsekwencji powyższe kwestie przekładają się na poziom handlu bronią w regionie ${ }^{4}$.

W niniejszym artykule poddano analizie kwestie dotyczące podejścia państw Ameryki Łacińskiej i Karaibów do porozumień związanych z handlem bronią. Ze względu na złożoność tematu, scharakteryzowane zostaną najważniejsze problemy dotyczące poziomu eksportu i importu uzbrojenia oraz sprzętu wojskowego, jak też główni dostawcy techniki wojskowej do państwa regionu.

Celem niniejszego artykułu jest przedstawienie poziomu handlu bronią w regionie Ameryki Łacińskiej i Karaibów w okresie 2008-2020. Przyjęto następujące hipotezy badawcze:

1. Eksport uzbrojenia i sprzętu wojskowego do państw regionu Ameryki Łacińskiej i Karaibów stanowi odwzorowanie znaczenia i poziomu sprzedaży broni przez najważniejszych dostawców na światowym rynku.

2. Państwa regionu Ameryki Łacińskiej i Karaibów mają marginalne znaczenie zarówno na regionalnymi jak i światowym rynku broni.

\section{POROZUMIENIACH ZWIĄZANYCH Z HANDLEM BRONIĄ}

Państwa regionu w różnym zakresie uczestniczą w porozumieniach obejmujących handel bronią. Do najważniejszych związanych z kontrolą i redukcją zbrojeń na poziomie globalnym zalicza się Traktat o handlu brona (ATT - Arms Trade Treaty) z 2013 roku. Uzupełnienie stanowi porozumienie dotyczące „broni niehumanitarnych", tj. Konwencja o zakazie użycia, składowania, produkcji

3 Stockholm International Peace Research Institute (SIPRI)

4 I. Topolski, The Military Standing of the Countries in Latin America and the Caribbean Region in the Period Between 2008-2020, „Anuario Latinoamericano - Ciencias Políticas y Relaciones Internacionales", Vol. 9, 2020, s. 137-167. 
i przekazywania min przeciwpiechotnych oraz ich zniszczenia (APMBC - Convention on the Prohibition of the Use, Stockpiling, Production and Transfer of Anti-Personnel Mines and on Their Destruction) - z roku 1999.

Natomiast w skali regionu należy wymienić dwa porozumienia:

a) Międzyamerykańska konwencja przeciwko nielegalnej produkcji i handlowi broni palnej, amunicji i innych związanych z tym materiałów (CIFTA - Inter-American Convention Against the Illicit Manufacturing of and Trafficking in Firearms, Ammunition, Explosives, and Other Related Materials) - podpisana 14 listopada 1997 r., weszła w życie 1 lipca 1998 r.;

b) Międzyamerykańska konwencja o przejrzystości w zakupach broni konwencjonalnej (IACTCW - Inter-American Convention on Transparency in Conventional Weapons Acquisitions) - podpisana 7 czerwca 1997 r., weszła w życie 21 listopada $2002 \mathrm{r}$.

Tabela 1. Udział państw regionu Ameryki Łacińskiej i Karaibów w porozumieniach związanych $\mathrm{z}$ handlem bronią

\begin{tabular}{|c|c|c|c|}
\hline $\begin{array}{l}\text { Porozu- } \\
\text { mienie }\end{array}$ & Ratyfikacja/ Akcesja & Podpisanie & Poza porozumieniem \\
\hline ATT & $\begin{array}{c}\text { Antigua i Barbuda, Argentyna, Bahamy, } \\
\text { Barbados, Belize, Brazylia, Chile, Do- } \\
\text { minika, Dominikana, Grenada, Gujana, } \\
\text { Gwatemala, Honduras, Jamajka, Kostaryka, } \\
\text { Meksyk, Panama, Paragwaj, Peru, Saint } \\
\text { Kitts i Nevis, Saint Lucia, Saint Vincent } \\
\text { i Grenadyny, Salwador, Surinam, Trinidad } \\
\text { i Tobago, Urugwaj }\end{array}$ & $\begin{array}{l}\text { Haiti, Ko- } \\
\text { lumbia }\end{array}$ & $\begin{array}{l}\text { Boliwia, Ekwador, } \\
\text { Kuba, Nikaragua, } \\
\text { Wenezuela }\end{array}$ \\
\hline CIFTA & $\begin{array}{c}\text { Antigua i Barbuda, Argentyna, Bahamy, } \\
\text { Barbados, Belize, Boliwia, Brazylia, Chile, } \\
\text { Dominika, Dominikana, Ekwador, Grenada, } \\
\text { Gujana, Gwatemala, Haiti, Honduras, Ko- } \\
\text { lumbia, Kostaryka, Meksyk, Nikaragua, } \\
\text { Panama, Paragwaj, Peru, Saint Kitts i Nevis, } \\
\text { Saint Lucia, Saint Vincent i Grenadyny, } \\
\text { Salwador, Surinam, Trinidad i Tobago, Uru- } \\
\text { gwaj, Wenezuela }\end{array}$ & Jamajka & Kuba \\
\hline IACTCW & $\begin{array}{l}\text { Argentyna, Barbados, Brazylia, Chile, Do- } \\
\text { minikana, Ekwador, Gwatemala, Kostaryka, } \\
\text { Meksyk, Nikaragua, Panama, Paragwaj, } \\
\text { Peru, Salwador, Urugwaj, Wenezuela }\end{array}$ & $\begin{array}{l}\text { Boliwia, } \\
\text { Dominika, } \\
\text { Haiti, Hon- } \\
\text { duras, Ko- } \\
\text { lumbia }\end{array}$ & $\begin{array}{l}\text { Antigua i Barbuda, } \\
\text { Bahamy, Belize, } \\
\text { Grenada, Gujana, } \\
\text { Jamajka, Kuba, Saint } \\
\text { Kitts i Nevis, Saint } \\
\text { Lucia, Saint Vincent } \\
\text { i Grenadyny, Surinam, } \\
\text { Trinidad i Tobago } \\
\end{array}$ \\
\hline APMBC & $\begin{array}{l}\text { Antigua i Barbuda, Argentyna Bahamy, } \\
\text { Barbados, Belize, Boliwia, Brazylia, Chile, } \\
\text { Dominika, Dominikana, Ekwador, Grenada, } \\
\text { Gujana, Gwatemala, Haiti, Honduras, Ja- } \\
\text { majka, Kolumbia, Kostaryka, Meksyk, }\end{array}$ & & Kuba \\
\hline
\end{tabular}




\begin{tabular}{|c|c|c|c|}
\hline $\begin{array}{c}\text { Porozu- } \\
\text { mienie }\end{array}$ & Ratyfikacja/ Akcesja & Podpisanie & Poza porozumieniem \\
\hline & $\begin{array}{c}\text { Nikaragua, Panama, Paragwaj, Peru, Saint } \\
\text { Kitts i Nevis, Saint Lucia, Saint Vincent } \\
\text { i Grenadyny, Salwador, Surinam, Trinidad } \\
\text { i Tobago, Urugwaj, Wenezuela }\end{array}$ & & \\
& & \\
\hline
\end{tabular}

Źródło: Arms Trade Treaty, URL <https://treaties.unoda.org/t/att>, [dostęp: 20.08.2021]; Convention on the Prohibition of the Use, Stockpiling, Production and Transfer of Anti-Personnel Mines and on Their Destruction, URL < https://treaties.unoda.org/t/mine_ban>, [dostęp: 10.12.2021]. Signatories and ratifications. A-63: Inter-American Convention Against the Illicit Manufacturing of and Trafficking in Firearms, Ammunition, Explosives, and Other Related Materials, URL <http:/www.oas.org/juridico/english/ sigs/a-63.html>, [dostęp: 21.03.2021]; A-63: Inter-American Convention Against the Illicit Manufacturing of and Trafficking in Firearms, Ammunition, Explosives, and Other Related Materials, URL <http://www. oas.org/juridico/english/sigs/a-63.html>, [dostęp: 21.03.2021]; Signatories and ratifications. A-64: InterAmerican Convention on Transparency in Conventional Weapons Acquisitions (A-64), URL <http://www. oas.org/juridico/english/sigs/a-64.html>, [dostęp: 21.03.2021]; Inter-American Convention on Transparency in Conventional Weapons Acquisitions, URL < http://www.oas.org/en/sla/dil/inter_american_treaties_A-64_ transparency_conventional_weapons_adquisiti ons.asp>, [dostęp: 21.03.2021].

W największym zakresie państwa regionu Ameryki Łacińskiej i Karaibów są stroną APMBC, gdyż poza konwencją pozostaje tylko Kuba. Dobrze należy także ocenić udział w CITFA, której nie ratyfikowała Jamajka, a Kuba nie podpisała. Natomiast w przypadku Traktatu o handlu bronia sytuacja jest znacznie gorsza. Porozumienia tego nie ratyfikowały dwa państwa (Haiti, Kolumbia), zaś pięć nie podpisało (Boliwia, Ekwador, Kuba, Nikaragua, Wenezuela). W przypadku czwartego porozumienia, tj. Międzyamerykańskiej konwencji o przejrzystości w zakupach broni konwencjonalnej, stroną jest szesnaście państwa, a pięć tylko podpisało, zaś dwanaście pozostaje poza nią. Stroną wszystkich porozumień jest łącznie 13 z 33 państw regionu, zalicza się do nich Argentynę, Barbados, Brazylię, Chile, Dominikanę, Gwatemalę, Kostarykę, Meksyk, Panamę, Paragwaj, Peru, Salwador i Urugwaj. Na przeciwległym biegunie znajduje się Kuba, która nie podpisała wszystkich porozumień. Natomiast cztery państwa pozostają poza dwoma porozumieniami, tj. Boliwia, Haiti, Kolumbia (ATT, IACTCW) oraz Jamajka (CIFTA, IACTCW) zob., tab. 1.

\section{POZIOM IMPORTU I EKSPORTU UZBROJENIA ORAZ SPRZECTU WOJSKOWEGO}

Eksport uzbrojenia ${ }^{5}$ państw Ameryki Łacińskiej i Karaibów w latach 20082020 wyniósł około 1,099 mld USD, co stanowiło prawie 0,31\% światowej sprzedaży. Dla porównania, Stany Zjednoczone Ameryki wyeksportowały broń o wartości ponad 108-razy większej, tj. na poziomie 118,763 mld USD i 33,43\%

5 Należy podkreślić, iż według SIPRI zarówno szacunkowy eksport oraz import uzbrojenia jest wyrównywany do pełnych mln USD, co może powodować pewne stosunkowo niewielkie różnice wartości - wielkości poniżej $0,5 \mathrm{mln}$ USD nie są uwzględniane. 
w skali świata. Uwzględniając całkowitą sprzedaż broni przez państwa Ameryki Łacińskiej i Karaibów w omawianym okresie, jest ona zbliżona do Zjednoczonych Emiratów Arabskich - 1,114 mld USD - pozycja nr 21, co stanowi ponad 0,31 światowego eksportu broni. W regionie zdecydowanym liderem jest Brazylia (896 mln USD), numer 22. na liście światowej (około 0,25\%), na którą przypada prawie $81,53 \%$ eksportu uzbrojenia. Pozycja numer 2. należy do Chile - $120 \mathrm{mln}$ USD i blisko 10,92\%. Kolejne miejsca zajmują odpowiednio Wenezuela (43 mln, 3,91\%), Kolumbia (25 mln, 2,28\%), Ekwador ( $8 \mathrm{mln}, 0,76 \%$ ), Dominikana (4 mln, 0,36\%), Argentyna, Meksyk, Panama (po około $1 \mathrm{mln}, 0,09 \%$ ). Natomiast Kostaryka i Bahamy sprzedały broń na poziomie poniżej $0,5 \mathrm{mln}$ USD, co nie zostało uwzględnione w statystykach SIPRI, zobacz tabela 2.

Tabela 2. Eksport i import uzbrojenia państw Ameryki Łacińskiej i Karaibów w porównaniu do wybranych państw w latach 2008-2020, w mln USD, według SIPRI

\begin{tabular}{|c|c|c|c|c|c|c|c|}
\hline \multicolumn{4}{|c|}{ Eksport uzbrojenia $^{a}$} & \multicolumn{4}{|c|}{ Import uzbrojenia $^{\mathrm{b}}$} \\
\hline Pozycja & Państwo & $\begin{array}{c}\mathrm{mln} \\
\text { USD }\end{array}$ & $\begin{array}{l}\text { Udział } \\
\mathrm{w}(\%) \\
\end{array}$ & Pozycja & Państwo & $\begin{array}{l}\mathrm{mln} \\
\text { USD }\end{array}$ & $\begin{array}{l}\text { Udział } \\
\text { w (\%) }\end{array}$ \\
\hline 1. & USA & 118763 & 34,43 & 1 & Indie & 39737 & 11,18 \\
\hline 2. & Rosja & 81642 & 22,98 & 2 & $\begin{array}{l}\text { Arabia } \\
\text { Saudyjska }\end{array}$ & 28375 & 7,99 \\
\hline 3. & Francja & 24187 & 6,81 & 3 & ChRL & 17008 & 4,79 \\
\hline 4. & RFN & 21632 & 6,09 & 4 & Australia & 14852 & 4,18 \\
\hline 5. & ChRL & 18369 & 5,17 & 5 & $\begin{array}{l}\text { Republika } \\
\text { Korei }\end{array}$ & 13602 & 3,83 \\
\hline 6. & W. Brytania & 14316 & 4,03 & 6 & Algieria & 13115 & 3,69 \\
\hline 7. & Hiszpania & 11237 & 3,16 & 7 & Pakistan & 13062 & 3,68 \\
\hline 8. & Izrael & 8516 & 2,40 & 8 & ZEA & 12931 & 3,64 \\
\hline 9. & Włochy & 8465 & 2,38 & 9 & Egipt & 12736 & 3,58 \\
\hline 10. & Niderlandy & 6876 & 1,93 & 10 & USA & 10047 & 2,83 \\
\hline 21 & $Z E A$ & 1114 & 0,31 & 22 & Wenezuela & 4117 & $\mathbf{2 6 , 0 4 / 1 , 1 6}$ \\
\hline 22 & Brazylia & 896 & $\mathbf{8 1 , 5 3 / 0 , 2 5}$ & 36 & Brazylia & 2728 & $\mathbf{1 7 , 2 5} / 0,77$ \\
\hline 41 & Chile & 120 & $\mathbf{1 0 , 9 2 / 0 , 0 3}$ & 39 & Chile & 2378 & $\mathbf{1 5 , 0 4 / 0 , 6 7}$ \\
\hline 50 & Wenezuela & 43 & $\mathbf{3 , 9 1 / 0 , 0 1}$ & 42 & Meksyk & 1943 & $\mathbf{1 2 , 2 9 / 0 , 5 5}$ \\
\hline 58 & Kolumbia & 25 & $2,28 /-$ & 45 & Kolumbia & 1708 & $\mathbf{1 0 , 8 0} / 0,48$ \\
\hline 64 & Ekwador & 8 & $\mathbf{0 , 7 3 / -}$ & 56 & Peru & 948 & $\mathbf{5 , 9 9 / 0 , 2 7}$ \\
\hline 70 & Dominikana & 4 & $0,36 /-$ & 66 & Ekwador & 591 & $\mathbf{3 , 7 4} / 0,17$ \\
\hline 74 & Argentyna & 1 & $0,09 /-$ & 92 & Argentyna & 243 & $\mathbf{1 , 5 4 / 0 , 0 7}$ \\
\hline 75 & Meksyk & 1 & $0,09 /-$ & 101 & Boliwia & 189 & $\mathbf{1 , 1 9 / 0 , 0 5}$ \\
\hline 76 & Panama & 1 & $0,09 /-$ & 103 & Urugwaj & 183 & $\mathbf{1 , 1 6 / 0 , 0 5}$ \\
\hline 80 & Kostaryka & $\mathbf{0}$ & $\mathbf{0} /-$ & 109 & Nikaragua & 148 & $\mathbf{0 , 9 3 / 0 , 0 4}$ \\
\hline 83 & Bahamy & $\mathbf{0}$ & $\mathbf{0} /-$ & 113 & $\begin{array}{l}\text { Trinidad } \\
\text { i Tobago }\end{array}$ & 124 & $\mathbf{0 , 7 8} / 0,03$ \\
\hline & & & & 118 & Panama & 80 & $\mathbf{0 , 5 0 / 0 , 0 2}$ \\
\hline & & & & 119 & Bahamy & 79 & $\mathbf{0 , 5 0} / 0,02$ \\
\hline & & & & 122 & Honduras & 76 & $\mathbf{0 , 4 8} / 0,02$ \\
\hline
\end{tabular}




\begin{tabular}{|c|c|c|c|c|c|c|c|}
\hline \multicolumn{4}{|c|}{ Eksport uzbrojenia $^{a}$} & \multicolumn{4}{|c|}{ Import uzbrojenia $^{\mathrm{b}}$} \\
\hline Pozycja & Państwo & $\begin{array}{c}\mathrm{mln} \\
\text { USD }\end{array}$ & $\begin{array}{l}\text { Udział } \\
\text { w (\%) }\end{array}$ & Pozycja & Państwo & $\begin{array}{c}\text { mln } \\
\text { USD }\end{array}$ & $\begin{array}{l}\text { Udział } \\
\text { w (\%) }\end{array}$ \\
\hline & & & & 124 & Dominikana & 73 & $\mathbf{0 , 4 6 / 0 , 0 2}$ \\
\hline & & & & 128 & Jamajka & 63 & $\mathbf{0 , 4 0 / 0 , 0 2}$ \\
\hline & & & & 131 & Gwatemala & 53 & $\mathbf{0 , 3 3} / 0,01$ \\
\hline & & & & 143 & Salwador & 32 & $\mathbf{0 , 2 0} / 0,01$ \\
\hline & & & & 148 & Paragwaj & 20 & $0,13 /-$ \\
\hline & & & & 150 & Barbados & 20 & $0,13 /-$ \\
\hline & & & & 164 & Surinam & 9 & $0,06 /-$ \\
\hline & & & & 176 & Gujana & 3 & $0,02 /-$ \\
\hline & & & & 181 & Belize & 2 & $0,01 /-$ \\
\hline & & & & 183 & Kostaryka & 2 & $0,01 /-$ \\
\hline & Region & 1099 & $\sim 0,31$ & & Region & 15812 & 4,45 \\
\hline & Cały świat & 355244 & 100,0 & & Cały świat & 355244 & 100,00 \\
\hline
\end{tabular}

a „Dziesięciu” największych eksporterów uzbrojenia - udział światowego rynku w procentach;

"„Dziesięciu” największych importerów uzbrojenia - udział światowego rynku w procentach.

Źródło: TIV of arms exports from the top 90 largest exporters, 2008-2020, URL <http://armstrade.sipri. org/armstrade/html/export_toplist.php>, [dostęp: 12.12.2021]; TIV of arms imports to the top 190 largest

importers, 2008-2020, URL <http://armstrade.sipri.org/armstrade/html/export_toplist.php>, [dostęp: 12.12.2021].

W okresie 2008-2020 import uzbrojenia przez państwa regionu Ameryki Łacińskiej i Karaibów szacowano na poziomie 15,812 mld USD co stanowiło około $4,45 \%$ światowych zakupów. Należy podkreślić, iż był on prawie 2,5-raza niższy od światowego lidera Indii, który wynosił 39,737 mld USD i blisko 11,18\% całości. Największa część przypadła na Wenezuelę (4,117 mld USD), co stanowiło około 26,04\% importu państw Ameryki Łacińskiej i Karaibów - pozycja numer 22. na świecie wśród największych importerów uzbrojenia (1,16\% zakupów broni). Drugie miejsce w regionie zajmowała Brazylia (2,728 mld USD i prawie 17,25\%, 36., 0,77\%), a trzecie Chile (2,378 mld USD, blisko 15,04\%, 39., 0,67\%). Kolejne pozycje zajęły: Meksyk (1,943 mld USD, ponad 12,29\%, 42., 0,55\%), Kolumbia (1,708 mld USD, 10,80\%, 45., 0,48\%), Peru (948 mln USD, 5,99\%, 56., 0,27\%), Ekwador (591 mln USD, 3,74\%, nr 66., 0,17\%), Argentyna (243 mln USD, 1,54\%, nr 92., 0,07\%), Boliwia (189 mln, 1,19\%, nr 101., 0,05\%), Urugwaj (183 mln USD, $1,16 \%$, nr 103., 0,05\%). W przypadku pozostałych państw regionu import uzbrojenia był na stosunkowo niższym poziomie, tj. poniżej $1 \%$ i wyniósł dla poszczególnych państw odpowiednio: Nikaragua (148 mln USD, 0,93\%, nr 109., 0,04\%), Trinidad i Tobago (124 mln, 0,78\%, nr 113., 0,03\%), Panama ( $80 \mathrm{mln}, 0,50 \%, 118$., 0,02\%), Bahamy (79 mln, 0,50\%, 119., 0,02\%), Honduras (76 mln, 0,48\%, 122 ., 0,02\%), Dominikana ( $73 \mathrm{mln}, 0,46 \%, 124 ., 0,02 \%)$, Jamajka (63 mln, 0,40\%, 128 ., 0,02\%), Gwatemala (53 mln, 0,33\%, 131., 0,01\%), Salwador (32 mln, 0,2\%, 143 ., 0,01\%), Paragwaj (20 mln, 0,13\%, 148.), Barbados (20 mln, 0,13\%, 150.), Surinam (9 mln, 0,06\%, 164.), Gujana (3 mln, 0,02\%, 176.), Belize ( $2 \mathrm{mln}, 0,01 \%, 181$.) i Kostaryka (2 mln USD, 0,01\%, 183.), zob. tabela 2. 


\section{GŁÓWNI DOSTAWCY UZBROJENIA}

Najważniejszym eksporterem broni i sprzętu wojskowego do państw Ameryki Łacińskiej i Karaibów w okresie 2008-2020 była Federacja Rosyjska (około 21,40\% całości sprzedaży). Pozycję numer dwa zajmowały Stany Zjednoczone Ameryki (17,77\%), a trzecią Niemcy (9,61\%). Eksport broni przez trzy czołowe państwa był na poziomie blisko 48,8\% całości sprzedaży. Do ważnych dostawców broni zalicza się jeszcze Francję (7,33\%), Niderlandy (7,09\%), Hiszpanię (6,68\%), Izrael (4,93\%), Chiny (4,26\%), Włochy (3,70\%), Wielką Brytanię (3,18\%) i Republikę Korei $(2,60 \%)$. Należy podkreślić, iż na trzydziestu dwóch eksporterów techniki wojskowej z poza regionu przypadało ponad $96,86 \%$ całości sprzedaży. Dla porównania, na jedenaście państw regionu zaś prawie 3,03\%, a na nieokreślonych dostawców $0,12 \%$. Bardzo duże dysproporcje de facto świadczą o preferowaniu zakupów uzbrojenia i sprzętu wojskowego u dostawców z poza Ameryki Łacińskiej i Karaibów, a szczególnie największych eksporterów, dominujących na rynku światowym. Sytuacja taka może oznaczać w pewnym stopniu uzależnienie w kontekście serwisowania techniki wojskowej od tych, zobacz tabela 3.

Tabela 3. Import uzbrojenia przez państwa regionu Ameryki Łacińskiej i Karaibów w latach 2008-2020, w mln USD, według SIPRI

\begin{tabular}{|c|c|c|c|}
\hline \multicolumn{4}{|c|}{ Główni dostawcy broni do państw regionu } \\
\hline Lp. & Państwo & mln USD & udział w (\%) \\
\hline & Dostawcy z poza regionu & & \\
\hline 1. & Rosja & 3384 & 21,40 \\
\hline 2. & USA & 2810 & 17,77 \\
\hline 3. & Niemcy & 1520 & 9,61 \\
\hline 4. & Francja & 1159 & 7,33 \\
\hline 5. & Niderlandy & 1122 & 7,09 \\
\hline 6. & Hiszpania & 1056 & 6,68 \\
\hline 7. & Izrael & 780 & 4,93 \\
\hline 8. & Chiny & 674 & 4,26 \\
\hline 9. & Włochy & 585 & 3,70 \\
\hline 10. & W. Brytania & 503 & 3,18 \\
\hline 11. & Republika Korei & 412 & 2,60 \\
\hline 12. & Kanada & 269 & 1,70 \\
\hline & Pozostali dostawcy & 1061 & 6,71 \\
\hline & Dostawcy z regionu & & \\
\hline & Brazylia & 276 & 1,74 \\
\hline & Chile & 120 & 0,76 \\
\hline & Pozostali region & 83 & 0,52 \\
\hline & Dostawcy z poza regionu & 15316 & 96,86 \\
\hline & Dostawcy nieznani & 19 & 0,12 \\
\hline
\end{tabular}




\begin{tabular}{|c|c|c|c|}
\hline \multicolumn{4}{|c|}{ Główni dostawcy broni do państw regionu } \\
\hline Lp. & Państwo & mln USD & udział w (\%) \\
\hline & Dostawcy z regionu & 479 & 3,03 \\
\hline & Import całkowity $^{\mathrm{a}}$ & 15812 & 100,00 \\
\hline
\end{tabular}

${ }^{a}$ należy zaznaczyć, iż wartość sumy importowanego uzbrojenia przez państwa Ameryki Ła cińskiej i Karaibów jest niższa o około 2 mln USD od szacunkowej wielkości podanej dla dostawców uzbrojenia.

Źródło: TIV of arms exports from Brazil, 2008-2020,<http://armstrade.sipri.org/armstrade/html/export_values. php>, [dostęp: 10.12.2021]; TIV of arms exports from Chile, 2008-2020, <http://armstrade.sipri.org/armstrade/ html/export_values.php>, [dostęp: 10.12.2021]; TIV of arms exports from Venezuela, 2008-2020, <http:// armstrade.sipri.org/armstrade/html/export_values.php>, [dostęp: 10.12.2021]; TIV of arms exports from Colombia, 2008-2020, <http://armstrade.sipri.org/armstrade/html/export_values.php>, [dostęp: 10.12.2021]; TIV of arms exports from Ecuador, 2008-2020, <http://armstrade.sipri.org/armstrade/html/export_values.php>, [dostęp: 10.12.2021]; TIV of arms exports from Dominican Republic, 2008-2020, <http://armstrade.sipri.org/ armstrade/html/export_values.php>, [dostęp: 10.12.2021]; TIV of arms exports from Argentina, 2008-2020, $<$ http://armstrade.sipri.org/armstrade/html/export_values.php $>$, [dostęp: 10.12.2021]; TIV of arms exports from Mexico, 2008-2020, <http://armstrade.sipri.org/armstrade/html/export_values.php>, [dostęp: 10.12.2021]; TIV of arms exports from Panama, 2008-2020, <http://armstrade.sipri.org/armstrade/html/export_values.php>,

[dostęp: 10.12.2021]; TIV of arms exports from Costa Rica, 2008-2020, <http://armstrade.sipri.org/armstrade/ html/export_values.php>, [dostęp: 10.12.2021]; TIV of arms exports from Bahamas, 2008-2020, <http:// armstrade.sipri.org/armstrade/html/export_values.php>, [dostęp: 10.12.2021]; TIV of arms exports from Russia, 2008-2020, URL <http://armstrade.sipri.org/armstrade/html/export_values.php>, [dostęp: 10.12.2021]; TIV of arms exports from United States, 2008-2020, URL < http://armstrade.sipri.org/armstrade/html/export_values. php>, [dostęp: 10.12.2021]; TIV of arms exports from Germany, 2008-2020, <http://armstrade.sipri.org/ armstrade/html/export_values.php>, [dostęp: 12.12.2021]; TIV of arms exports from France, 2008-2020, URL < http://armstrade.sipri.org/armstrade/html/export_values.php>, [dostęp: 12.12.2021]; TIV of arms exports from Netherlands, 2008-2020, URL <http://armstrade.sipri.org/armstrade/html/export_values.php>, [dostęp: 11.12.2021]; TIV of arms exports from Spain, 2008-2020, URL <http://armstrade.sipri.org/armstrade/ html/export_values.php>, [dostęp: 12.12.2021]; TIV of arms exports from Israel, 2008-2020, URL <http:// armstrade.sipri.org/armstrade/html/export_values.php>, [dostęp: 09.12.2021]; TIV of arms exports from China, 2008-2020, URL <http://armstrade.sipri.org/armstrade/html/export_values.php>, [dostęp: 09.12.2021]; TIV of arms exports from Italy, 2008-2020, URL <http://armstrade.sipri.org/armstrade/html/export_values.php >, [dostęp: 09.12.2021]; TIV of arms exports from United Kingdom, 2008-2020, URL <http://armstrade.sipri.org/ armstrade/html/export_values.php>, [dostęp: 09.12.2021]; TIV of arms exports from South Korea, 2008-2020, $\mathrm{URL}<\mathrm{http}$ //armstrade.sipri.org/armstrade/html/export_values.php >, [dostęp: 09.12.2021]; TIV of arms exports from Canada, 2008-2020, URL <http://armstrade.sipri.org/armstrade/html/export_values.php>, [dostęp:

09.12.2021]; TIV of arms exports from Australia, 2008-2020, <http://armstrade.sipri.org/armstrade/html/export values.php>, [dostęp: 12.12.2021]; TIV of arms exports from Ukraine, 2008-2020, URL < http://armstrade. sipri.org/armstrade/html/export_values.php>, [dostęp: 09.12.2021]; TIV of arms exports from Portugal, 2008-2020, URL < http://armstrade.sipri.org/armstrade/html/export_values.php>, [dostęp: 09.12.2021]; TIV of arms exports from South Africa, 2008-2020, URL < http://armstrade.sipri.org/armstrade/html/export_values. php>, [dostęp: 09.12.2021]; TIV of arms exports from Norway, 2008-2020, URL < http://armstrade.sipri.org/ armstrade/html/export_values.php>, [dostęp: 09.12.2021]; TIV of arms exports from Sweden, 2008-2020, URL

$<\mathrm{http}$ //armstrade.sipri.org/armstrade/html/export_values.php>, [dostęp: 09.12.2021]; TIV of arms exports from Switzerland, 2008-2021, URL <http://armstrade.sipri.org/armstrade/html/export_values.php>, [dostęp: 09.12.2021]; TIV of arms exports from Denmark, 2008-2020, URL <http://armstrade.sipri.org/armstrade/html/ export_values.php>, [dostęp: 12.12.2021]; TIV of arms exports from India, 2008-2020, <http://armstrade.sipri. org/armstrade/html/export_values.php>, [dostęp: 12.12.2021]; TIV of arms exports from Finland, 2008-2020, $<$ http://armstrade.sipri.org/armstrade/html/export_values.php $>$, [dostęp: 12.12.2021]; TIV of arms exports from Jordan, 2008-2020, <http://armstrade.sipri.org/armstrade/html/export_values.php>, [dostęp: 12.12.2021]; TIV of arms exports from Unknown supplier(s), 2008-2020, <http://armstrade.sipri.org/armstrade/html/export values.php>, [dostęp: 12.12.2021]; TIV of arms exports from Austria, 2008-2020, <http://armstrade.sipri.org/ armstrade/html/export_values.php>, [dostęp: 12.12.2021]; TIV of arms exports from New Zealand, 2008-2020, $<\mathrm{http}$ //armstrade.sipri.org/armstrade/html/export_values.php $>$, [dostęp: 12.12.2021]; TIV of arms exports from Taiwan, 2008-2020<http://armstrade.sipri.org/armstrade/html/export_values.php>, [dostęp: 12.12.2021]; TIV of arms exports from Czechia, 2008-2020, <http://armstrade.sipri.org/armstrade/html/export_values.php>, 
[dostęp: 12.12.2021]; TIV of arms exports from Ireland, 2008-2020, <http://armstrade.sipri.org/armstrade/html/ export_values.php>, [dostęp: 12.12.2021]; TIV of arms exports from Turkey, 2008-2020, <http://armstrade.sipri. org/armstrade/html/export_values.php>, [dostęp: 12.12.2021]; TIV of arms exports from Belgium, 2008-2020, $<\mathrm{http}$ :/armstrade.sipri.org/armstrade/html/export_values.php $>$, [dostęp: 12.12.2021]; TIV of arms exports from Poland, 2008-2020, <http://armstrade.sipri.org/armstrade/html/export_values.php>, [dostęp: 12.12.2021]; TIV of arms exports from Iran, 2008-2020, <http://armstrade.sipri.org/armstrade/html/export_values.php>, [dostęp: 12.12.2021].

Eksport Rosji do ośmiu państw regionu wynosił około 3384 mln USD. Na poszczególne państwa przypadało odpowiednio: Wenezuela (2750 mln USD), Peru (232 mln), Brazylia (175 mln), Nikaragua (134 mln), Kolumbia (34 mln), Meksyk (27 mln), Ekwador (18 mln), Argentyna (14 mln USD) ${ }^{6}$.

W latach 2008-2020 Stany Zjednoczone Ameryki dostarczyły do dwudziestu jeden państw Ameryki Łacińskiej i Karaibów broń oraz wyposażenie na sumę $2810 \mathrm{mln}$ USD. Należały do nich Meksyk (857 mln), Kolumbia (643 mln), Brazylia (540 mln), Chile (475 mln), Argentyna (128 mln), Peru (37 mln), Panama (31 mln), Jamajka (29 mln), Trinidad i Tobago (24 mln), Ekwador (10 mln), Boliwia (8 mln), Salwador i Wenezuela (po $6 \mathrm{mln}$ ), Gwatemala (5 mln), Honduras (4 mln), Kostaryka i Paragwaj (po 2 mln), Bahamy, Dominikana i Urugwaj (po $1 \mathrm{mln}$ ) oraz Surinam (poniżej $0,5 \mathrm{mln}$ USD) ${ }^{7}$.

Eksport Niemiec do dziesięciu państw regionu był na poziomie $1520 \mathrm{mln}$ USD, w tym do Chile (599 mln USD), (Brazylii (551 mln), Kolumbii (251 mln), Wenezueli (68 mln), Peru i Boliwii (po $13 \mathrm{mln}$ ), Ekwadoru i Meksyku (po 10 $\mathrm{mln})$, Argentyny (4 mln) i Panamy (1 mln $)^{8}$. Francja dostarczyła broń o wartości 1159 mln USD do dziesięciu państw Ameryki Łacińskiej i Karaibów, tj.: Brazylii (469 mln), Chile (213 mln), Meksyku (210 mln), Boliwii (97 mln), Peru (66 mln), Argentynie (46 mln), Kolumbii (28 mln), Ekwadoru (20 mln) Surinamu (7 mln) i Urugwaj (3 mln) .

Niderlandy eksportowały uzbrojenie do dwunastu państw Ameryki Łacińskiej i Karaibów o wartości $1122 \mathrm{mln}$ USD - Meksyku (335 mln), Chile (212 mln), Wenezueli (145 mln), Peru (94 mln), Kolumbii (79 mln), Bahamów (77 mln), Trynidadu i Tobago (60 mln), Ekwadoru (37 mln), Jamajki (30 mln), Barbadosu i Hondurasu (po $20 \mathrm{mln}$ ), Nikaragui $(13 \mathrm{mln})^{10}$. Hiszpania sprzedała do jedenastu państw regionu technikę wojskową na sumę około 1056 mln USD, w tym Wenezueli (313 mln), Meksyku (302 mln), Kolumbii (91 mln), Ekwadoru ( $88 \mathrm{mln}$ ), Brazylii ( $84 \mathrm{mln})$, Chile (81 mln mln), Urugwaj (45 mln), Gwatemali (33 mln), Argentyny (14 mln), Boliwii (3 mln), Salwador $(2 \mathrm{mln})^{11}$.

\footnotetext{
TIV of arms exports from Russia, 2008-2020...

TIV of arms exports from United States...

TIV of arms exports from Germany...

TIV of arms exports from France...

${ }_{10}$ TIV of arms exports from Netherlands...

11 TIV of arms exports from Spain...
} 
W analizowanym okresie Izrael dostarczył uzbrojenie do dziesięciu państw regionu o wartości $780 \mathrm{mln}$ USD, tj. Kolumbii (331 mln), Brazylii (228 mln), Chile (69 mln), Hondurasu (36 mln), Meksyku i Dominikany (po $33 \mathrm{mln}$ USD), Peru (27 mln), Paragwaju (12 mln), Ekwadoru (7 mln), Salwadoru (4 mln $)^{12}$. Dostawy uzbrojenia przez Chiny do siedmiu państw wyniosły około $674 \mathrm{mln}$ USD, a mianowicie Wenezueli (588 mln), Boliwii (46 mln), Trinidadu i Tobago (16 mln), Peru (15 mln), Ekwadoru (8 mln), Argentyny (1 mln) oraz Bahamów (poniżej $0,5 \mathrm{mln})^{13}$.

Jedenaście państw regionu zakupiło we Włoszech broń o wartości $585 \mathrm{mln}$ USD, tj.: Brazylia (226 mln), Peru (104 mln), Chile (95 mln), Meksyk (74 mln), Panama (42 mln), Wenezuela (20 mln), Ekwador (8 mln) Argentyna i Kolumbia (po $7 \mathrm{mln}$ ), Urugwaj $(2 \mathrm{mln} \text { ) i Bahany (poniżej } 0,5 \mathrm{mln})^{14}$. Natomiast Wielka Brytania wyeksportowała uzbrojenie do siedmiu państw Ameryki Łacińskiej i Karaibów na sumę $503 \mathrm{mln}$ USD. Należały do nich: Brazylia (297 mln USD), Chile (169 mln), Kolumbia (11 mln), Boliwia, Peru i Ekwador (po $8 \mathrm{mln}$ ) oraz Gujana $(2 \mathrm{mln})^{15}$. Republika Korei dostarczyła technikę wojskową do Peru, Kolumbii i Ekwadoru odpowiednio o wartości $272 \mathrm{mln}, 128 \mathrm{mln}$ i $12 \mathrm{mln}$ USD $^{16}$. Eksport broni z Kanady objął jedenaście państw regionu o wartości 269 mln USD. Należały do nich Meksyk (71 mln USD), Peru (48 mln), Brazylia (39 mln), Kolumbia (31 mln), Urugwaj (18 mln), Ekwador i Chile (po $17 \mathrm{mln})$, Argentyna (16 mln), Panama (5 mln), Dominikana (4 mln), Gwatemala (3 mln $)^{17}$.

Do pozostałych dostawców uzbrojenia i sprzętu wojskowego do państw Ameryki Łacińskiej i Karaibów należy zaliczyć jeszcze Australię (267 mln Chile, Trinidad i Tobago, Jamajka), Ukrainę (201 mln - Wenezuela, Peru, Boliwia), Portugalię (109 mln - Urugwaj, Chile, Kolumbia), Republikę Południowej Afryki (96 mln - Ekwador), Norwegię ( $81 \mathrm{mln}$ - Chile, Brazylia), Szwecję (67 mln - Brazylia, Meksyk Urugwaj, Argentyna), Szwajcarię (63 mln - Wenezuela, Brazylia, Argentyna), Danię (32 mln - Brazylia, Meksyk, Kolumbia, Peru), Indie (30 mln - Ekwador, Surinam), Finlandię (28 mln - Chile, Kolumbia), Jordanię (13 mln - Brazylia), Austrię (12 mln - Wenezuela, Argentyna, Boliwia, Jamajka), Nową Zelandię (12 mln - Peru), Tajwan (10 mln - Honduras, Belize, Gwatemala, Paragwaj, Panama), Czechy (5 mln - Brazylia, Meksyk, Boliwia), Irlandię (5 mln - Chile), Turcję (4 mln - Kolumbia), Belgię ( $3 \mathrm{mln}$ - Chile, Urugwaj), Polskę (3 $\mathrm{mln}$ - Ekwador), Iran (1 mln - Wenezuelę) oraz nieznanych dostawców (ponad

\footnotetext{
12 TIV of arms exports from Israel...

13 TIV of arms exports from China...

14 TIV of arms exports from Italy...

15 TIV of arms exports from United Kingdom...

16 TIV of arms exports from South Korea...

17 TIV of arms exports from Canada...
} 
19 mln - Chile, Argentyna, Urugwaj, Ekwador, Honduras, Boliwia, Jamajka, Kolumbia, Wenezuela $)^{18}$.

Ponadto należy także wskazać na Brazylię, która w analizowanym okresie dostarczyła sprzęt i uzbrojenie do ośmiu państw, a mianowicie Chile $(97 \mathrm{mln})$, Ekwadoru (79 mln), Kolumbii (45 mln), Dominikany (35 mln), Urugwaju (13 $\mathrm{mln}$ ), Boliwii (4 mln), Paragwaju (3 mln) i Gujany (poniżej $0,5 \mathrm{mln})^{19}$. Na uwagę zasługuje również Chile, które do trzech państw regionu sprzedało broń o wartości ponad $120 \mathrm{mln}$ USD, a mianowicie: Ekwadoru (100 mln), Salwadoru (20 $\mathrm{mln}$ ) oraz Urugwaju (poniżej $0,5 \mathrm{mln})^{20}$. Natomiast pozostałe państwa regionu dostarczyły broń o wartości około $78 \mathrm{mln}$ USD, w tym ${ }^{21}$ :

a) Wenezuela ( $43 \mathrm{mln})$ - Ekwador (40 mln), Boliwia (3 mln), Gwatemala (poniżej 0,5 $\mathrm{mln}$ );

b) Kolumbia ( $25 \mathrm{mln})$ - Gwatemala (10 mln), Honduras (10 mln), Peru (4 $\mathrm{mln}$ ), Surinam (poniżej $0,5 \mathrm{mln}$ );

c) Ekwador ( $8 \mathrm{mln})$ - Urugwaj ( $8 \mathrm{mln})$;

d) Dominikana (4 mln) - Kolumbia (4 mln);

e) Argentyna (1 mln) - Paragwaj (1 mln);

f) Meksyk (1 mln) - Ekwador (1 mln);

g) Panama (1 mln) - Ekwador (1 mln);

h) Kostaryka (poniżej 0,5 mln) - Gujana;

i) Bahamy (poniżej 0,5 mln).

Reasumując, import uzbrojenie i sprzętu wojskowego przez państwa Ameryki Łacińskiej i Karaibów jest pokrywany w stosunkowo niewielkim stopniu przez dostawców z regionu. Ponadto prawie $3 / 5$ broni sprzedawanej przez państwa regionu na światowym rynku uzbrojenia trafia do odbiorów w innych regionach międzynarodowych.

${ }^{18}$ TIV of arms exports from Australia...; TIV of arms exports from Ukraine...; TIV of arms exports from Portugal...; TIV of arms exports from South Africa...; TIV of arms exports from Norway...; TIV of arms exports from Sweden ...; TIV of arms exports from Switzerland...; TIV of arms exports from Denmark...; TIV of arms exports from India ...; TIV of arms exports from Finland...; TIV of arms exports from Jordan...; TIV of arms exports from Unknown supplier(s)...; TIV of arms exports from Austria...; TIV of arms exports from New Zealand...; TIV of arms exports from Taiwan...; TIV of arms exports from Czechia...; TIV of arms exports from Ireland...; TIV of arms exports from Turkey...; TIV of arms exports from Belgium...; TIV of arms exports from Poland...; TIV of arms exports from Iran...

19 TIV of arms exports from Brazil...

${ }^{20}$ TIV of arms exports from Chile...

${ }^{21}$ TIV of arms exports from Venezuela...; TIV of arms exports from Colombia...; TIV of arms exports from Ecuador...; TIV of arms exports from Dominican Republic...; TIV of arms exports from Argentina...; TIV of arms exports from Mexico...; TIV of arms exports from Panama ...; TIV of arms exports from Costa Rica...; TIV of arms exports from Bahamas... 


\title{
$* * *$
}

Handel bronią w regionie Ameryki Łacińskiej i Karaibów jest on bardzo zróżnicowany. Zdecydowanie dominuje import uzbrojenia nad eksportem - ponad 15-krotnie. Dodatkowo w przypadku sprzedaży, jak i zakupów broni przez państwa regionu występują pomiędzy nimi bardzo duże dysproporcje. Szczególnie jest to widoczne w kontekście eksportu uzbrojenia przez Brazylię wobec pozostałych państw - dominująca pozycja w skali regionu. Natomiast w porównaniu do czołowych dostawców na rynku broni jest ona stosunkowo niska.

Przyjęte we Wstępie niniejszego artykułu hipotezy badawcze sprawdziły się tylko częściowo. Po pierwsze eksport uzbrojenia i sprzętu wojskowego do państw regionu Ameryki Łacińskiej i Karaibów tylko w pewnym zakresie odwzorowuje znaczenia i poziom sprzedaży broni przez najważniejszych dostawców na świecie. Mimo, iż Federacja Rosyjska oraz Stany Zjednoczone Ameryki są najważniejszymi dostawcami broni na tym rynku, jednak ich przewaga nie jest tak duża jak w skali całego świata. Ponadto eksport Rosji jest uzależniony od zakupów Wenezueli. Natomiast większa dywersyfikacja występuje w przypadku USA.

Po drugie, państwa Ameryki Łacińskiej i Karaibów mają marginalne znaczenie na światowym rynku broni. Natomiast w przypadku rynku regionalnego, na ich tle wyróżnia się Brazylia. W przyszłości jej znacznie jako dostawcy uzbrojenia dla innych państw regionu może ulec zwiększeniu.

\begin{abstract}
Summary: Arms trade affects the expansion of the military potential of a country, and thus, its international military stature. Indirectly, it is also connected with the treaties involving armaments control, in particular, the ones pertaining to arms transfer and military equipment. The military stature of Latin America and the Caribbean countries is extremely diversified. In addition, some of these countries have undertaken the modernisation of their armies, which is linked to arms purchases. Consequently, it leads to the emergence of various sub-regional arms races. Despite the existence of territorial and border disputes, the region is considered to be stable and the risk of an international military conflict outbreak is low. On the other hand, predominant, non-military threats of internal nature, existing in Latin America and the Caribbean, have a considerable impact on maintaining the homeland security. These problems translate to the level of arms trade in the region. In the following article, the approach of the countries of Latin America and the Caribbean towards the treaties involving armaments control have been analysed. Due to the complexity of this issue, only the most significant problems concerning export and import of arms and military equipment will be characterised. Moreover, the main suppliers of military technology to the countries of the region will be listed.
\end{abstract}

Key Words: Latin America and the Caribbean, arms trade, Arms Trade Treaties, arms suppliers, arms import, arms export 


\section{BIBLIOGRAFIA}

Dokumenty i materiały

1. Arms Trade Treaty, URL < https://treaties.unoda.org/t/att $>$.

2. Convention on the Prohibition of the Use, Stockpiling, Production and Transfer of Anti-Personnel Mines and on Their Destruction, URL $<\mathrm{https}$ ://treaties.unoda.org/t/mine_ban>.

3. Signatories and ratifications. A-63: Inter-American Convention Against the Illicit Manufacturing of and Trafficking in Firearms, Ammunition, Explosives, and Other Related Materials, URL $<\mathrm{http} / /$ www.oas.org/juridico/english/sigs/a-63.html >

4. A-63: Inter-American Convention Against the Illicit Manufacturing of and Trafficking in Firearms, Ammunition, Explosives, and Other Related Materials, URL < http://www.oas.org/jurid$\mathrm{ico} /$ english/sigs/a-63.html>.

5. Signatories and ratifications. A-64: Inter-American Convention on Transparency in Conventional Weapons Acquisitions (A-64), URL < http://www.oas.org/juridico/english/sigs/a-64.html>.

6. Inter-American Convention on Transparency in Conventional Weapons Acquisitions, URL $<$ http://www.oas.org/en/sla/dil/inter_american_treaties_A-64_transparency_conventional_weapons_adquisiti ons.asp $>$.

Artykuły. Monografie. Opracowania

1. Krzywicka K., Ameryka Łacińska i Karaiby, [w:] Międzynarodowe Stosunki Polityczne, M. Pietraś (red.), Lublin 2021

2. Międzynarodowe Stosunki Polityczne, M. Pietraś (red.), Lublin 2021

3. The Military Balance 2021, International Institute for Strategic Studies, London 2021

4. Topolski I., Kontrola i redukcja zbrojeń, [w:] Międzynarodowe Stosunki Polityczne, M. Pietraś (red.), Lublin 2021

5. Topolski, The Military Standing of the Countries in Latin America and the Caribbean Region in the Period Between 2008-2020, „Anuario Latinoamericano - Ciencias Políticas y Relaciones Internacionales", Vol. 9, 2020

\section{Źródła internetowe}

1. Stockholm International Peace Research Institute, URL < https://www.sipri.org/>. 